\title{
The Effects of Aquilaria malaccensis Leaves Aqueous Extract on Sperm of Sprague Dawley Rats towards Early Embryogenesis
}

Faridah Ismail ${ }^{a}$, Azantee Yazmie Abdul Wahab ${ }^{b}$, Muhammad Lokman Md Isa ${ }^{c}$, Hussin Muhammad ${ }^{d}$, Raja Arif Shah Raja Ismail ${ }^{b}$, Redzuan Nul Hakim Abdul Razak

aDepartment of Basic Medical Sciences, Kulliyyah of Medicine, International Islamic University of Malaysia, Kuantan Campus, Pahang, Malaysia

bepartment of Obstetrics \& Gynaecology, Kulliyyah of Medicine, International Islamic University of Malaysia, Kuantan Campus, Pahang, Malaysia

'Department of Basic Medical Sciences, Kulliyyah of Nursing, International Islamic University of Malaysia, Kuantan Campus, Pahang, Malaysia

${ }^{\mathrm{d} H e r b a l}$ Medicine Research Centre, Institute for Medical Research, Jalan Pahang, 50588 Kuala Lumpur, Malaysia

${ }^{e}$ Department of Basic Medical Sciences, Kulliyyah of Allied Health Sciences, International Islamic University of Malaysia, Kuantan Campus, Pahang, Malaysia

\section{ABSTRACT}

Introduction: Oxidative stress induced by excessive and unopposed levels of reactive oxygen species in male reproductive system results in impaired sperm quality, fertilization capacity and poor embryo development. Our goal is to assess the potential effects of Aquilaria malaccensis (AM) leaves, a plant with strong antioxidant property on early embryo development in vitro and embryo quality following fertilization with cyclophosphamide (CP) exposed rat sperm. Materials and Methods: Twenty four male Sprague Dawley rats were allocated into eight groups of three rats $(n=3)$ : control, CP only $(200 \mathrm{mg} / \mathrm{kg}), A M$ only $(100 \mathrm{mg} / \mathrm{kg}$, $300 \mathrm{mg} / \mathrm{kg}$ and $500 \mathrm{mg} / \mathrm{kg})$ and $C P+A M(100 \mathrm{mg} / \mathrm{kg}, 300 \mathrm{mg} / \mathrm{kg}$ and $500 \mathrm{mg} / \mathrm{kg})$. Animals were sacrificed after 63 days of treatment and sperm from caudal epididymis were taken for in vitro fertilization (IVF) with oocytes from untreated female. Fertilization, embryo division and embryo morphology were examined at 8 and 48 hours post insemination and compared between groups. Statistical evaluations were performed using Chi-Square test and Fisher's exact test and $p$-value $<0.05$ was considered significant. Results: Administration of $A M$ leave extract at $100 \mathrm{mg} / \mathrm{kg} /$ day to normal rats and CP-exposed rats has significantly increased $(p<0.05)$ the fertilization rate, early cleavage rate and embryo quality when compared to CP only treated group. However, other groups showed no significant differences. Conclusion: Overall, the present results indicate the potential of $A M$ leave extract supplementation to improve the fertility and early embryo development in male rat exposed to $\mathrm{CP}$ by inhibiting the oxidative processes and scavenging free radicals.

KEYWORDS: Aquilaria malaccensis, Cyclophosphamide, In Vitro Fertilization, Embryo, Natural antioxidant

\section{INTRODUCTION}

Oxidative stress (OS) has been widely implicated as

\section{Corresponding author:}

Dr. Azantee Yazmie Abdul Wahab

Department of Obstetrics \& Gynecology,

Faculty of Medicine,

International Islamic University of Malaysia,

Jalan Sultan Ahmad Shah,

25200 Kuantan, Pahang, Malaysia.

Tel No: $+609-5704000 / 2155$

E-mail: yazmie@iium.edu.my one of the important mechanisms in the pathophysiology of male infertility. Under physiological condition, human spermatozoa produces small amount of reactive oxygen species (ROS) to induce capacitation, acrosomal reaction and acquisition of sperm fertilizing ability. However, excessive generation of ROS accompanied by low scavenging and antioxidant levels in semen will lead to induction of OS. The high levels of ROS mainly superoxide anion, hydroxyl radical and hydrogen peroxide will interfere with membrane lipids, proteins and DNA of the sperm and subsequently harm its motility, viability, morphology as well as the 
membrane fusion events such as the acrosome reaction and sperm-oocyte fusion. ${ }^{1-3}$ Studies have shown that high levels of ROS were detected in 25 $40 \%$ of the semen of infertile men, in contrast to low levels in fertile men. ${ }^{4,5}$ Moreover, significant negative correlations have been detected between OS and semen parameters, fertilization rate, embryo development and pregnancy rate. ${ }^{6}$

The origins of ROS in seminal plasma could arise from either endogenous factors including immature or abnormal sperms, infection, varicocele, cancer or exogenous factors such as exposure to drugs, chemicals, heat or radiation, smoking, stress and obesity. ${ }^{3}$ Cyclophosphamide (CP), a widely used anticancer and immunosuppressive agent, is well known to induce reproductive toxicity in human as well as rodents as a result of oxidative stress. ${ }^{7}$ One of the CP metabolites, acrolein has been proven to increase lipid peroxidation, induce oxidative damage, cytoskeletal abnormalities, and decrease the viability of Sertoli cells in the testis. Furthermore, this toxic alkylating agent also increases the susceptibility of sperm to oxidative attack by alkylating the free thiols on sperm protamines and significantly impairs the chromatin compaction. ${ }^{8}$ An increased incidence of oligospermia and azoospermia were observed in male cancer patients treated with $\mathrm{CP}$ and some of them even suffered permanent sterility. ${ }^{9}$ Apart from that, previous studies on male rats also revealed the potential of CP to cause histological alterations in the testis and epididymis as well as disturbance in gonadotropins and testosterone secretions in blood. ${ }^{10,11} \mathrm{CP}$ administration to adult male rats were also reported to adversely affect the offspring by increasing pre- and post-implantation loss, inducing foetal malformations as well as growth retardation. ${ }^{12}$ Due to the significant testicular damage and sterility caused by $C P$, this drug was used to generate subfertile rat model in this study and high dose of 200 $\mathrm{mg} / \mathrm{kg}$ was chosen. ${ }^{13,14}$

Antioxidants are molecules that act to prevent or intercepting the deleterious effects of free radicals by stabilizing or deactivating them. Three levels of protection offered by antioxidant defence mechanisms include prevention, interception and repair. ${ }^{3,15}$ In order to balance the deleterious ROS effects, seminal plasma and spermatozoa have developed antioxidant systems which comprise of enzymatic antioxidants including superoxide dismutase, catalase, glutathione peroxidase, glutathione transferase, and ceruloplasmin; and non -enzymatic antioxidants including albumin, $B$ carotenes, L-carnitine, glutathione, pyruvate, taurine, hypotaurine, ubiquinol, vitamin C (ascorbic acid), vitamin E (a-tocopherol), and zinc. ${ }^{16}$ It has been reported that semen from fertile men has a higher total antioxidant capacity (TAC) than semen from infertile men. ${ }^{17}$ To date, the beneficial effects of oral antioxidant therapy in patients with impaired sperm quality have been well documented in several reviews of clinical studies. ${ }^{2,18,19}$ For example, it has been demonstrated that vitamin E, C and Menevit (combined oral antioxidants) supplementations in male patients undergoing IVF or ICSI treatment have led to significant increase in fertilization rates, implantation rates and pregnancy outcome. ${ }^{20-22}$

Aquilaria species (agarwood) from the Thymelaeaceae family is one of the most precious plants on earth and has been used in religious, aromatic and medicinal preparation since thousands of years. ${ }^{23,24}$ In folk medicine, its common uses include inflammatory-related ailments such as arthritis, asthma, gout, acting as aphrodisiac and stimulant as well as sedative and carminative agent. ${ }^{25}$ Recently, variety of their parts including leaves, skin, seeds, wood and roots were shown to be valuable in medicinal properties. Aquilaria malaccensis (AM) is one of the most common Aquilaria species found in Malaysia and was shown to exhibit potent antioxidant, analgesic, antipyretic, anti-inflammatory, antihyperglycemic and antimicrobial activities. ${ }^{25,26}$ Although this plant has been reported to have medicinal purposes towards various kinds of diseases, information on its effect on male fertility and reproduction is very scarce Therefore, the present study was undertaken to evaluate the possibilities of $A M$ in improving sperm fertilizing ability and subsequent early embryo development in vitro following toxic paternal exposure to cyclophosphamide.

\section{MATERIALS \& METHODS}

\section{Plant material}

The leaves were collected from $A M$ tree plantation in Forest Research Institute Malaysia (FRIM) at Kepong, Selangor. The specimen voucher PIIUM 0296 
was prepared and deposited at Natural Medicinal Product Centre, Kulliyyah of Pharmacy, International Islamic University Malaysia (IIUM).

\section{Preparation of the aqueous extract}

The fresh leaves were dried in drying oven at $40{ }^{\circ} \mathrm{C}$ and powdered with an electric blender. $150 \mathrm{~g}$ of dried leaves powder was soaked in $1500 \mathrm{ml}$ of $40{ }^{\circ} \mathrm{C}$ hot distilled water and placed in sonicator for 30 minutes. The hot-water extract was filtered through Whatman No. 1 filter paper and the extraction steps were repeated twice. The resulting filtrates were then freeze-dried and the powder yield was stored at $4^{\circ} \mathrm{C}$ in air-tight bottle until further use. The average (W/W) yield was $10 \%$.

\section{Animals}

Sixty-four Sprague Dawley rats (24 males and 30 females) at 10-12 weeks old with weight between 150-200g were acclimatized for a week before starting the treatment. The animals were kept in polycarbonate cages inside a well-ventilated room with temperature $22^{\mp} 2^{\circ} \mathrm{C}$, maintained under standard laboratory conditions with $50^{ \pm} 10 \%$ humidity and a cycle of $12 \mathrm{~h}$ light and $12 \mathrm{~h}$ dark. Standard laboratory animal feed and water were provided ad libitum. All ethical themes of studies on animals were considered carefully, and the experimental protocol was approved by the Institutional Animal Care and Use Committee of the International Islamic University Malaysia (IACUCIIUM) with the reference number IIUM/IACUC Approval / 2017 (15).

\section{Experimental protocol}

The male rats were randomly divided into eight groups consisting of three animals each $(n=3)$. Group 1 served as normal control and only received distilled water orally. Group 2 received single intraperitoneal injection of CP $(200 \mathrm{mg} / \mathrm{kg})$ only on day 1of treatment. Groups 3-5 received supplementation of $\mathrm{AM}$ leaves extract daily at concentration of $100 \mathrm{mg} / \mathrm{kg} /$ day, $300 \mathrm{mg} / \mathrm{kg} /$ day, and $500 \mathrm{mg} / \mathrm{kg} /$ day respectively via oral gavage. While Groups 6-8 were given single intraperitoneal injection of CP $(200 \mathrm{mg} / \mathrm{kg})$ on day 1 of treatment, followed by $A M$ leaves extract supplementation daily at doses of $100 \mathrm{mg} / \mathrm{kg} /$ day, $300 \mathrm{mg} / \mathrm{kg} /$ day and $500 \mathrm{mg} / \mathrm{kg} /$ day respectively for each group via oral gavage.

\section{Sperm collection}

The method used for IVF was a modification of that described by Toyoda and Chang. ${ }^{27,28}$ One day prior to IVF procedures, culture dishes containing drops of fertilization and culture media (LifeGlobal), 30-50 $\mu \mathrm{L}$ each covered with mineral oil were prepared and placed in incubator $\left(37^{\circ} \mathrm{C}, 5 \% \mathrm{CO}_{2}\right.$ in air) overnight to allow them to gas equilibrate. The male rats were euthanized after 63 days of treatment by injection of sodium pentobarbital $(60 \mathrm{mg} / \mathrm{kg})$ intraperitoneally and their cauda epididymides were removed. The epididymal sperm were collected by chopping one cauda epididymis in petri dish containing $4 \mathrm{ml}$ of sperm washing media (IrvineScientific). The sperm suspension were left in the $\mathrm{CO}_{2}$ incubator $\left(37^{\circ} \mathrm{C}, 5 \%\right.$ $\mathrm{CO}_{2}$ in air) for at least 1 hour to allow the sperm to swim up and capacitate before proceeded with IVF. Sperm from cauda epididymis were used because these sperm have gained full maturity and motility. Thus, higher potential for fertilization can be achieved.

\section{Oocytes collection and insemination}

For collection of ovulated oocytes, female rats were killed on the day of oestrous, which was identified by examination of vaginal smears. The oviducts were removed and kept in handling media (LifeGlobal). The oviducts were then torn open using a dissecting needle and the oocytes were released from within, collected and introduced into the drop of preincubated fertilization media in the culture dishes using the micropipette. Using the tip of pipette, appropriate amount of the preincubated sperm suspension were added to the fertilization media containing the oocytes and the dishes were placed in incubator $\left(37^{\circ} \mathrm{C}, 5 \% \mathrm{CO}_{2}\right.$ in air).

\section{Embryo evaluation and grading}

About 20-24 hours after insemination, the oocytes were examined for evidence of sperm penetration by means of an inverted phase-contrast microscope. Fertilized oocytes were then washed and transferred into new droplets of culture media and embryo development was assessed again at 48 hours and 72 hours post insemination. The presence of early 
embryo cleavage and several morphological parameters of the embryos were evaluated. Cleaved embryos scoring was applied based on the number of cells, the appearance of blastomeres and the presence of cytoplasm defects or fragmentation as described by Baczkowski et al. Grading based on symmetry of blastomere were as follow; Type A: equal size blastomeres; Type $\mathrm{B}$ : unequal size blastomere and Type C: defects of cytoplasm. Additionally, grading based on degree of fragmentation includes; Grade I: no fragmentation; Grade II: fragmentation less than 30\%; Grade III: fragmentation between $30-50 \%$ and Grade IV: fragmentation more than $50 \%{ }^{29}$

\section{Statistical analysis}

Statistical evaluations were performed using ChiSquare test and Fisher's exact test. SPSS version 21.0 was used for statistical analysis and $p$ value $<0.05$ was considered significant in this study.

\section{RESULTS}

\section{Fertilization rate and early embryo cleavage}

Table I presents the fertilization, four-cell and eight -cell cleavage rates of IVF cultures for each group. The rates were calculated as the number of fertilized oocytes (presence of two pro-nuclei), 4cell stage (number of 4 -cells embryos 48 hours post insemination) and 8-cell stage embryos (number of 8 cells embryos 72 hours post insemination) divided by the total number of oocytes observed per group respectively. Significant increase $(p<0.05)$ in the rate of fertilization and 4-cell stage embryo development were seen in the group treated with $\mathrm{AM}$ at dose $100 \mathrm{mg} / \mathrm{kg}(\mathrm{AM}-100)$ compared to the CP only group. Co-treatment of $C P$ exposed rats with $A M$ at same dose $(C P+A M-100)$ also resulted in significantly higher $(p<0.05)$ fertilization rate compared to CP only group. However, other groups have no significant difference in comparison with control and CP group.

\section{Fragmentation degree of embryos}

The percentage of embryos graded based on degree of fragmentation is presented in Table II. As shown in the table, CP only group failed to produce any grade 1 embryo. Treatment with $\mathrm{AM}$ at dose $100 \mathrm{mg} /$ $\mathrm{kg}$ (AM-100), $300 \mathrm{mg} / \mathrm{kg}$ (AM-300), $500 \mathrm{mg} / \mathrm{kg}$ (AM$500)$ as well as the co-administration of this extract to $\mathrm{CP}$ exposed rats at dose $100 \mathrm{mg} / \mathrm{kg}(\mathrm{CP}+\mathrm{AM}-100)$ produced significantly higher $(p<0.05)$ grade 1 or good quality embryos compared to CP only group. However, for grade II and III, there is no significant difference between all the groups. While for grade IV, the statistic is not available as only one grade IV embryo produced during the IVF.

Table I: The effects of cyclophosphamide (CP) and Aquilaria malaccensis (AM) leave aqueous extract on fertilization and early cleavage rates following for in vitro fertilization (IVF)

\begin{tabular}{|c|c|c|c|c|}
\hline Group & $\begin{array}{l}\text { No. of } \\
\text { oocytes }\end{array}$ & $\begin{array}{l}\text { Fertilization } \\
\text { rate }\end{array}$ & $\begin{array}{l}\text { 4-cell } \\
\text { rate }\end{array}$ & $\begin{array}{l}8 \text {-cell } \\
\text { rate }\end{array}$ \\
\hline Control & 33 & $52 \%(17)$ & $39 \%(13)$ & $30 \%(10)$ \\
\hline$C P$ & 30 & $30 \%(9)$ & $\begin{array}{l}20 \% \\
(6)\end{array}$ & $17 \%(5)$ \\
\hline$A M-100$ & 37 & $62 \%(23)^{\dagger}$ & $\begin{array}{c}43 \% \\
(16)^{\dagger}\end{array}$ & $32 \%(12)$ \\
\hline$A M-300$ & 35 & $37 \%(13)$ & $\begin{array}{l}23 \% \\
(8)\end{array}$ & $17 \%(6)$ \\
\hline$A M-500$ & 33 & $45 \%(15)$ & $\begin{array}{l}30 \% \\
(10)\end{array}$ & $21 \%(7)$ \\
\hline$C P+A M-100$ & 35 & $57 \%(20)^{\dagger}$ & $\begin{array}{l}40 \% \\
(14)\end{array}$ & $29 \%(10)$ \\
\hline$C P+A M-300$ & 32 & $28 \%(9)$ & $\begin{array}{l}19 \% \\
(6)\end{array}$ & $16 \%(5)$ \\
\hline$C P+A M-500$ & 33 & $24 \%(8)$ & $\begin{array}{l}15 \% \\
(5)\end{array}$ & $12 \%(4)$ \\
\hline
\end{tabular}

Data is presented in percentage.

${ }^{\dagger}$ Significantly different from CP group, $p$-value $<0.05$ (ChiSquare test).

Abbreviation: $\mathrm{CP}=$ Cyclophosphamide; $\mathrm{AM}-100=$ Aquilaria malaccensis $100 \mathrm{mg} / \mathrm{kg} / \mathrm{day} ; \mathrm{AM}-300=$ Aquilaria malaccensis $300 \mathrm{mg} / \mathrm{kg} /$ day; $\mathrm{AM}-500=$ Aquilaria malaccensis $500 \mathrm{mg} / \mathrm{kg} / \mathrm{day}$

\section{Blastomere structure of embryos}

Table III shows the percentage of embryos graded based on symmetry of the blastomeres. There was no significant difference in the structure of the blastomere including type A, type B and type C between all the groups. Descriptively, most of the embryos produced in all groups were under type $B$ (unequal size blastomere) and CP only treated group indicated highest percentage of type $C$ (defects of cytoplasm) embryos.

\section{DISCUSSION}

One of the important determinants for successful fertilization and embryo development in vitro is the sperm quality. ${ }^{30}$ Many studies have demonstrated low 
fertilization rates, cleavage rates and embryo quality associated with poor semen parameters, indicating a very early onset of paternal effects on embryo development. These significant parameters include reduced sperm concentration, motility and high percentage of morphologically abnormal sperm as a result of impaired spermatogenesis. The quality of DNA in the sperm head can also influence embryo development. ${ }^{31,32}$ Clinical studies have proven that infertile men possess more sperm DNA damage in the ejaculate than do healthy subjects. Using sperm containing high loads of DNA damage during ART has led to poor embryo development and early pregnancy loss. ${ }^{33}$

Table II: The effects of cyclophosphamide (CP) and Aquilaria malaccensis (AM) leave aqueous extract on fragmentation degree of cleavage stage rat embryos

\begin{tabular}{lccccc}
\hline Group & Grade I & Grade II & $\begin{array}{l}\text { Grade } \\
\text { III }\end{array}$ & $\begin{array}{l}\text { Grade } \\
\text { IV }\end{array}$ & Total \\
\hline Control & $41 \%(7)$ & $41 \%(7)$ & $18 \%(3)$ & $0 \%(0)$ & $\begin{array}{c}100 \% \\
(17)\end{array}$ \\
CP & $0 \%(0)$ & $75 \%(6)$ & $25 \%(2)$ & $0 \%(0)$ & $\begin{array}{c}100 \% \\
(8)\end{array}$ \\
AM-100 & $48 \%(11)$ & $48 \%(11)$ & $4 \%(1)$ & $0 \%(0)$ & $100 \%$ \\
& + & & & & $(23)$ \\
AM-300 & $54 \%$ & $38 \%(5)$ & $8 \%(1)$ & $0 \%(0)$ & $100 \%$ \\
& $(7)^{\dagger}$ & & & & $(13)$ \\
AM-500 & $50 \%(7)^{\dagger}$ & $43 \%(6)$ & $7 \%(1)$ & $0 \%(0)$ & $100 \%$ \\
& & & & & $(14)$ \\
CP+AM- & $45 \%(9)^{\dagger}$ & $30 \%(6)$ & $20 \%(4)$ & $5 \%(1)$ & $100 \%$ \\
100 & & & & & $(20)$ \\
CP+AM- & $33 \%(3)$ & $67 \%(6)$ & $0 \%(0)$ & $0 \%(0)$ & $100 \%$ \\
300 & & & & & $(9)$ \\
CP+AM- & $14 \%(1)$ & $43 \%(3)$ & $43 \%(3)$ & $0 \%(0)$ & $100 \%$ \\
500 & & & & & $(7)$ \\
\hline Data & & & & &
\end{tabular}

Data is presented in percentage.

${ }^{\dagger}$ Significantly different from CP group, $p$-value $<0.05$

(Fisher's exact test)

Abbreviation: $\mathrm{CP}=$ Cyclophosphamide; $\mathrm{AM}-100=$ Aquilaria malaccensis $100 \mathrm{mg} / \mathrm{kg} / \mathrm{day} ; \mathrm{AM}-300=$ Aquilaria malaccensis $300 \mathrm{mg} / \mathrm{kg} / \mathrm{day} ; \mathrm{AM}-500=$ Aquilaria malaccensis $500 \mathrm{mg} / \mathrm{kg} /$ day

Evaluation of the embryo morphology has become the primary method to evaluate embryo development and viability as well as to select embryos for transfer during IVF. One of the important steps in embryo evaluation is made 24-28 hours post insemination, when the early cleavage stage begins. It has been demonstrated that cleavage rate, blastomere symmetry, cytoplasmic appearance, extent of fragmentation and blastomere nucleus status are the most essential morphological features that can efficiently predict blastocyst formation and implantation. ${ }^{29,34}$ For example, previous studies have shown that high percentage of fragmentations formed in the embryo was associated with poor implantation potential. ${ }^{35} \mathrm{~A}$ number of factors can influence the embryo quality produced during IVF, including environment of the culture as well as genetic materials transferred from both parents. Few reports have revealed that higher degree of embryo fragmentation was observed in patients with high sperm DNA fragmentation. ${ }^{36}$

Table III: The effects of cyclophosphamide (CP) and Aquilaria malaccensis (AM) leave aqueous extract on blastomeres structure of cleavage stage rat embryos

\begin{tabular}{lcccc}
\hline Group & Types A & Types B & Types C & Total \\
\hline Control & $12 \%(2)$ & $59 \%(10)$ & $29 \%(5)$ & $\begin{array}{c}100 \% \\
(17)\end{array}$ \\
CP & $13 \%(1)$ & $50 \%(4)$ & $38 \%(3)$ & $\begin{array}{c}100 \% \\
(8)\end{array}$ \\
& & & & $100 \%$ \\
AM-100 & $26 \%(6)$ & $61 \%(14)$ & $13 \%(3)$ & $(23)$ \\
AM-300 & $8 \%(1)$ & $77 \%(10)$ & $15 \%(2)$ & $100 \%$ \\
& & & & $(13)$ \\
AM-500 & $21 \%(3)$ & $64 \%(9)$ & $14 \%(2)$ & $100 \%$ \\
& & & & $(14)$ \\
CP+AM- & $20 \%(4)$ & $55 \%(11)$ & $25 \%(5)$ & $100 \%$ \\
100 & & & & $(20)$ \\
CP+AM- & $33 \%(3)$ & $56 \%(5)$ & $11 \%(1)$ & $100 \%$ \\
300 & & & & $(9)$ \\
CP+AM- & $14 \%(1)$ & $71 \%(5)$ & $14 \%(1)$ & $100 \%$ \\
500 & & & & $(7)$ \\
\hline
\end{tabular}

Data is presented in percentage.

†Significantly different from CP group, $p$-value $<0.05$ (Fisher's exact test).

Abbreviation: $\mathrm{CP}=$ Cyclophosphamide; $\mathrm{AM}-100=$ Aquilaria malaccensis $100 \mathrm{mg} / \mathrm{kg} / \mathrm{day} ; \mathrm{AM}-300=$ Aquilaria malaccensis $300 \mathrm{mg} / \mathrm{kg} / \mathrm{day} ; \mathrm{AM}-500=$ Aquilaria malaccensis $500 \mathrm{mg} / \mathrm{kg} /$ day

In this study, acute exposure of male rats to high dose of CP was expected to impair sperm parameters and consequently affect the IVF outcome. Cyclophosphamide is known to induce both structural and functional sperm impairment by exerting direct toxic effect on DNA of the male germ cells and causing peroxidation of polyunsaturated fatty acids in plasma membranes of spermatozoa by generation of free radicals. ${ }^{37}$ These sperm defects are associated with low sperm fertilizing capacity and poor embryo development if fertilization occurs, due to DNA damage transmission to zygote. ${ }^{12} \mathrm{~A}$ 
number of studies have revealed that paternal exposure to $C P$ causes a decrease proliferation in cleavage-stage embryos, a laggard cell division pattern and a reduction in blastomere number and cell to cell contacts. ${ }^{38}$ In our study, the major findings showed that concurrent administration of $\mathrm{AM}$ leaves extract at $100 \mathrm{mg} / \mathrm{kg}$ to male rats after $C P$ exposure significantly improve the fertilization rate and reduce embryo fragmentation following IVF. This indicates that AM leaves extract at 100 $\mathrm{mg} / \mathrm{kg}$ has the potential to reduce free-radicals mediated sperm damage induced by $C P$ and improve the sperm DNA integrity. Thus, sperm structure and function can be enhanced and more fertilization and good embryo development can be achieved.

To the best of our knowledge, the current study is the first to investigate the effects of Aquilaria species specifically Aquilaria malaccensis (AM) on male reproduction and the resulting IVF outcome. Increasing evidences support the fact that $A M$ is advantageous where free radicals are known to play a predominant role in toxicity such as cancers and diabetes. $^{39}$ Studies on different extracts of A.malaccensis leaves including hexane, methanol, ethyl-acetate, and water showed that these extracts exhibited strong antioxidant and free radical scavenging activity. Moreover, it was reported that highest total phenolic content were manifested by water extract of the dried AM leaves. 26,40-42 Administration of $A$. malaccensis bark extract to mice via gavage was also demonstrated to increase physical fitness and sexual activities such as kissing vagina and mounting as well as the sperm parameters including sperm count and motility. ${ }^{43}$ It was also reported that $A$. malaccensis have cytotoxic activity towards cancer cells line and can serve as an alternative treatments for several types of cancer. Cytotoxic measure of $A$. malaccensis oil showed high cytotoxic activity towards colon (HCT116) cancer cell line and able to inhibit up to $99 \%$ of the cancer cells. ${ }^{44}$ The essential oil was also observed to possess anticancer activity towards MCF -7 breast cancer cells, where it showed cumulative effect of the cell killing, inhibition of the cell attachment and causing the cells to detach. ${ }^{45}$ These important pharmacological properties are attributed to the presence of many bioactive chemical constituents such as alkaloids, tannins, phenols, terpenoids, quinones and flavonoids, which are known to possess high antioxidant activity and provide protection against cells damage and substantially reduce the risk of developing chronic disease. ${ }^{26,41,42}$

However, our study indicates that $A M$ at dose 300 $\mathrm{mg} / \mathrm{kg}$ and $500 \mathrm{mg} / \mathrm{kg}$ showed no improvement in fertilization, cleavage rates or embryo grading when administered to CP treated rats. Generally, AM leave aqueous extract administration is considered safe and the $A M$ dosage should not cause any negative effects on sperm and embryo. Previous study indicated that $\mathrm{AM}$ leave extract administration up to $520 \mathrm{mg} / \mathrm{kg}$ daily for 90 days in male mice does not cause toxic symptoms and is safe for consumption. ${ }^{46}$ The $L D_{50}$ of the leaves extract was also found to be above $2000 \mathrm{mg} / \mathrm{kg}$. ${ }^{47}$ Moreover, significant increase in grade 1 embryos in IVF of normal rats supplemented with $\mathrm{AM}$ at dose $300 \mathrm{mg} / \mathrm{kg}$ and 500 $\mathrm{mg} / \mathrm{kg}$ indicates the potential benefits of $\mathrm{AM}$ on embryo development at this dosage. Possible factors that may explained the insignificant effects of $A M$ at these doses include improper handling of gametes and embryo during IVF procedures or environmental factors during embryo culture such as 'hypoxic' in vitro environment, visible light or infection. These factors can cause injury to the cells, induce free radical generation and subsequently impair the fertilization process and embryo division. ${ }^{6,48}$ Therefore, replication of the study with higher sample size is needed to prove the validity of the findings. In addition, evaluation of AM leaves extract toxicity in vitro using cell lines can be done to optimize the toxicity studies.

\section{CONCLUSION}

In conclusion, the findings of our study indicate that AM co-administration following paternal CP exposure has the potential to protect the male gametes from cellular and structural damage, improve the sperm fertilizing capacity and subsequent embryo development by inhibiting the oxidative processes and scavenging free radicals. However, additional research work is needed to further elucidate the mechanism of protective role of $A M$ in $C P$ inducedtoxic manifestation and to investigate the most efficient compound responsible for the therapeutic effects.

\section{DECLARATION OF INTEREST}

The authors declare no conflict of interest. 


\section{ACKNOWLEDGEMENTS}

The author would like to thank the Department of Basic Medical Sciences, Kulliyyah of Medicine and Centre for Post- graduate Studies, International Islamic University Malaysia.

\section{REFERENCES}

1. Agarwal A. Role of oxidative stress in male infertility and antioxidant supplementation. In: Business briefing: US kidney \& urological disease [online]. Available at: http://clevelandclinic.org/ reproductiveresearchcenter/docs/ publications/209_Agarwal. Accessed December 17, 2017.

2. Gharagozloo P, Aitken, RJ. The role of sperm oxidative stress in male infertility and the significance of oral antioxidant therapy. Hum Reprod 2011; 26:1628-40.

3. Sikka SC. Role of oxidative stress and antioxidants in andrology and assisted reproductive technology. J Androl 2004; 25:518.

4. Iwasaki A, Gagnon C. Formation of reactive oxygen species in spermatozoa of infertile patients. Fertil Steril 1992; 57:409-16.

5. Lamirande ED, Gagnon C. Impact of reactive oxygen species on spermatozoa: a balancing act between beneficial and detrimental effects. Hum Reprod 1995; 10:15-21.

6. Gupta S, Sekhon L, Agarwal A. The role of oxidative stress and antioxidants in assisted reproduction. Curr Wom Health Rev 2010; 6:227-38.

7. Chabra A, Shokrzadeh M, Naghshvar F, Salehi $F$, Ahmadi A. Melatonin ameliorates oxidative stress and reproductive toxicity induced by cyclophosphamide in male mice. Hum Exp Toxicol 2014; 33:185-96.

8. Codrington AM, Hales BF, Robaire B. Exposure of male rats to cyclophosphamide alters the chromatin structure and basic proteome in spermatozoa. Hum Reprod 2007; 22:1431-42.

9. Elangovan N, Chiou TJ, Tzeng WF, Chu ST. Cyclophosphamide treatment causes impairment of sperm and its fertilizing ability in mice. Toxicology 2006; 222:60-70.

10. Jalali AS, Hassanzadeh S, Malekinejad H. Chemoprotective effect of Crataegus monogyna aqueous extract against cyclophosphamide-induced reproductive toxicity. Vet Res Forum 2011; 2:266-73.

11. Ghosh D, Das UB, Ghosh S, Mallick M, Debnath J. Testicular gametogenic and steroidogenic activities in cyclophosphamide treated rat: a correlative study with testicular oxidative stress. Drug Chem Toxicol 2001; 25:281-92.

12. Hales BF, Barton TS, Robaire B. Impact of paternal exposure to chemotherapy on offspring in the rat. J Natl Cancer Inst Monogr 2005; 6:28-31.

13. Fukushima T, Yamamoto T, Kikkawa R, et al. Effects of male reproductive toxicants on gene expression in rat testes. J Toxicol Sci 2005; 30:195-206.

14. Matsui H, Mitsumori K, Yasuhara K, et al. Morphological evaluation of cyclophosphamide testicular toxicity in rats using quantitative morphometry of spermatogenic cycle stages. J Toxicol Sci 1995; 20:407-14

15. Agarwal A, Majzoub A. Role of antioxidants in male infertility. BJUI Knowledge 2016; 1-9.

16. Ko EY, Sabanegh ES Jr, Agarwal A. Male infertility testing : reactive oxygen species and antioxidant capacity. Fertil Steril 2014; 102:1518-27.

17. Lewis SEM, Boyle PM, Mckinney KA, et al. Total antioxidant capacity of seminal plasma is different in fertile and infertile men. Fertil Steril 1995; 64:868-70.

18. Agarwal A, Sekhon LH. The role of antioxidant therapy in the treatment of male infertility. Hum Fertile (Camb) 2010; 13:217-25.

19. Lombardo F, Sansone A, Romanelli F, et al. The role of antioxidant therapy in the treatment of male infertility : an overview. Asian J Androl 2011; 13:690-7.

20. Geva E. The effect of antioxidant treatment on human spermatozoa and fertilization rate in an in vitro fertilization program. Fertil and Steril 1996; 66:430-34.

21. Greco $E$, Romano $S$, lacobelli $M$ et al. ICSI in cases of sperm DNA damage : beneficial effect of oral antioxidant treatment. Hum Reprod 2005; 20:2590-94.

22. Tremellen K, Miari G, Froiland D, Thompson J. A randomised control trial examining the effect of an antioxidant (Menevit ) on pregnancy outcome during IVF-ICSI treatment. Aust N Z J Obstet Gynaecol 2007; 47:216-21.

23. Barden A, Anak NA, Mulliken T, Song M. Heart of the matter: Agarwood use and trade and CITES implementation for Aquilaria 
malaccensis. In: TRAFFIC International, Cambridge (United Kingdom) [online]. Available at: https://portals.iucn.org/library/ efiles/documents/Traf-072.pdf 072.pdf 1-52. Accessed June 10, 2017.

24. Lim TW, Noorainie AA. Wood for the Trees: a review of the agarwood (gaharu) trade in Malaysia. In: TRAFFIC Southeast Asia, Petaling Jaya, Malaysia [online]. Available at: http:// www.trafficj. org/ publication/10_Wood_for_the_trees.pdf. Accessed June, 2017.

25. Hashim YZHS, Kerr PG, Abbas P, Mohd Salleh $H$. Aquilaria spp. (agarwood) as source of health beneficial compounds: A review of traditional use, phytochemistry and pharmacology. J Ethnopharmacol 2016; 189:331-60.

26. Nik Wil NNA, Noor Adila MO, Ibrahim NA, Tajuddin SN. In vitro antioxidant activity and phytochemical screening of Aquilaria malaccensis leaf extracts. J Chem Pharm Res 2014; 6:688-93.

27. Toyoda Y, Chang MC. Fertilization of rat eggs in vitro by epididymal spermatozoa and the development of eggs following transfer. J Reprod Fert 1974; 36:9-22.

28. Aoto T, Takahashi R, Ueda M. A protocol for rat in vitro fertilization during conventional laboratory working hours. Transgenic Res 2011; 20:1245-52.

29. Baczkowski T, Kurzawa R, Glabowski W. Methods of embryo scoring in in vitro fertilization. Reprod Biol 2004; 4:5-22.

30. Tesarik J. Paternal effects on cell division in the human preimplantation embryo. Reprod Biomed Online 2005; 10:370-5.

31. Loutradi KE, Tarlatzis BC, Goulis DG, et al. The effects of sperm quality on embryo development after intracytoplasmic sperm injection. J Assisst Reprod Genet 2006; 23:6974.

32. Parinaud J, Mieusset R, Vieitez G, Labal B, Richoilley G. Influence of sperm parameters on embryo quality. Fertil Steril 1993; 60:888-92.

33. Morris ID, Ilott S, Dixon L, Brison DR. The spectrum of DNA damage in human sperm assessed by single cell gel electrophoresis ( Comet assay) and its relationship to fertilization and embryo development. Hum Reprod 2002; 17:990-8.

34. Gardner DK, Balaban B. Assessment of human embryo development using morphological criteria in an era of time-lapse, algorithms and " OMICS" : is looking good still important?. Mol Hum Reprod 2016; 22:704-18.

35. Erenus $M$, Zouves $C$, Rajamahendran $P$, et al. The effect of embryo quality on subsequent pregnancy rates after in vitro fertilization. Fertil Steril 1991; 56:707-10.

36. Simon L, Brunborg $G$, Stevenson $M$, et al. Clinical significance of sperm DNA damage in assisted reproduction outcome. Hum Reprod 2010; 25:1594-608.

37. Ceribasi AO, Turk G, Sonmez M, Sakin F, Atessahin A. Toxic effect of cyclophosphamide on sperm morphology, testicular histology and blood oxidant-antioxidant balance, and protective roles of lycopene and ellagic acid. Basic Clin Pharmacol Toxicol 2010; 107:730-6.

38. Harrouk W, Codrington A, Vinson R, Robaire B, Hales BF. Paternal exposure to cyclophosphamide induces DNA damage and alters the expression of DNA repair genes in the rat preimplantation embryo. Mutat Res 2000; 461:229-41.

39. Jok VA, Che Radzi N, Ku Hamid KH. A review: Pharmacological properties of Aquilaria spp. Adv Mat Res 2015; 1113:193-7.

40. Huda AWN, Munira MAS, Fitry SD, Salmah M. Antioxidant activity of Aquilaria malaccensis (thymelaeaceae) leaves. Pharmacognosy Res 2009; 1:270-3.

41. Begum Y. Study on Agarwood ( Aquilaria malaccensis ) to evaluate antibacterial and antioxidant activities of $\mathrm{n}$-hexane, chloroform and ethyl acetate extracts. Pharmatutor 2016; 4:47-50.

42. Hendra H, Moeljopawiro S, Nuringtyas TR. Antioxidant and antibacterial activities of Agarwood (Aquilaria malaccensis Lamk.) leaves. AIP Conference Proceedings 2016; 1755:14000.

43. Ruyani A, Sundaryono A. Pengembangan Kulit Batang Gaharu (Aquilaria malaccensis) sebagai perngsang seks (aphrodisiac) di Provinsi Bengkulu. In: UNIB Scholar Repository [online]. Available at: http:// repository.unib.ac.id/297/. Accessed September 29, 2018.

44. Ibrahim AH, Al-Rawi SS, Abdul Majid AMS, et al. Separation and fractionation of Aquilaria Malaccensis oil using supercritical fluid extraction and the cytotoxic properties of the 
extracted oil. Procedia Food Sci 2011; 1:1953-

9.

45. Hashim YZHY, Phirdaous A, Azura A. Screening of anticancer activity from agarwood essential oil. Pharmacognosy Res 2014; 6:191-4.

46. Batubara R, Surjanto, Sihombing TM, Ginting H. Keamanan teh gaharu ( Aquilaria malaccensis ) dari pohon induksi melalui uji toksisitas subkronik oral 90 hari. Biofarmasi 2016; 14:69-76.

47. Adam AZ, Tajuddin SN, Sudmoon R, et al. Chemical constituents and toxicity effects of leaves from several agarwood tree species ( Aquilaria ). J Trop For Sci 2018; 30:342-53.

48. Agarwal A, Said TM, Bedaiwy MA, Banerjee J, Alvarez JG. Oxidative stress in an assisted reproductive techniques setting. Fertil Steril 
